\title{
Addressing the Limits of Production Resources Through Partnerships to Improve Technical Efficiency: A Case Study of Micro and Small Industries in Indonesia 2014
}

\author{
Gayatri Waditra Nirwesti ${ }^{1}$ \\ Nachrowi Djalal Nachrowi ${ }^{2}$ \\ University of Indonesia
}

Ministry of National Development Planning/BAPPENAS

\begin{abstract}
The objective of the study is to understand the correlation between inter-firm cooperation and firm technical efficiency. It based on the background of the difficulties and limited production resources faced by micro and small industry (MSI) that impede them to move toward production frontier that makes firm less efficient technically. Therefore, this study will discuss whether cooperation conducted by MSI will bring improved technical efficiency. Estimation is taken by using maximum likelihood method on firm production function stochastically. Using data from Micro and Small Industry Survey Year 2004 published by National Bureau of Statistic of Indonesia, inter-firm cooperation is measured through index with Principal Component Analysis which reflects the degree of the cooperation. As the first study in Indonesia for the topic, result shows a positive correlation between inter-firm cooperation and technical efficiency in micro industry, otherwise the correlation is not found in small industry. This indicate that inter-firm cooperation is not "panacea" to attain technical efficiency, yet it is depending on the size of the firm.
\end{abstract}

Keywords: Inter-firm cooperation, micro and small industry, technical efficiency, production frontier, principal component analysis 
Mengatasi Keterbatasan Sumber Daya Produksi Melalui Kemitraan untuk Meningkatkan Efisiensi Teknis: Studi Kasus Industri Mikro dan Kecil di Indonesia Tahun 2014

Gayatri Waditra Nirwesti - BAPPENAS, Nachrowi Djalal Nachrowi - UI

\section{Pendahuluan}

Konsep kemitraan sejauh ini belum banyak dikaji oleh peneliti dan ekonom dalam kaitannya dengan efisiensi teknis perusahaan. Meskipun demikian, sudah ada pernyataan yang menyebutkan bahwa kemitraan (interfirm cooperation) merupakan salah satu hal yang membuat perusahaan menjadi efisien secara teknis (Burki dan Terrel, 1998). Maka, konsep ini sesungguhnya layak dipertimbangkan dan dipandang ideal untuk ditiru oleh negara berkembang. Dalam konteks industri manufaktur di Indonesia, kemitraan khususnya pada Industri Mikro (IM), dengan jumlah tenaga kerja 1-4 orang, dan Industri Kecil (IK) yang mempekerjakan 5-19 orang, menjadi relevan untuk dipahami karena beberapa latar belakang. Pertama, kemitraan sebagai strategi perusahaan (Tambunan, 2008) dalam menjawab keterbatasan dan tantangan usaha yang dihadapi perusahaan. Kecilnya skala usaha (smallness) membuat Industri Mikro dan Kecil (IMK) kerap terbentur permasalahan skala ekonomi (economies of scale) dalam sumberdaya produksi. Masalah-masalah ini dikaji dalam berbagai literatur meliputi kapasitas teknologi, manajemen produksi, pemasaran produk dan akses finansial yang rendah, serta kurangnya akses pada sistem pendukung lainnya (Berry dan Mazumdar, 1991; Urata, 2000). Permasalahan perolehan kapital, permodalan (kredit), informalitas, ketersediaan bahan baku, akses terhadap informasi, pemasaran dan distribusi produk, biaya transportasi, serta tenaga kerja (seperti kualitas dan upah) juga disampaikan (Nichter dan Goldmark, 2009; Tambunan, 2008; Essien dan Bello, 2007; Alvarez dan Crespi, 2001; Malecki dan Tootle, 1996). Sejalan dengan fakta ini, Badan Pusat Statistik (BPS) juga menyampaikan hal yang sama. Dari survei pada lebih dari 60 ribu IMK di Indonesia tahun 2014, sebanyak 70 persen menyatakan menghadapi kesulitan usaha. Kesulitan-kesulitan yang paling banyak disebutkan adalah permodalan $(30,68 \%)$, pemasaran $(16,95)$, dan bahan baku $(16,84 \%)$. Dua diantaranya, yaitu permodalan dan bahan baku merupakan faktor input yang sangat mempengaruhi produksi perusahaan dan efisiensi teknis. Masalah keterbatasan ini mengganggu proses produksi, baik dalam bentuk peningkatan biaya input misalnya karena adanya perubahan harga bahan baku, maupun dalam hal kualitas tenaga kerja dalam produksi. Hal ini membuat IMK akan cenderung berproduksi dibawah apa yang disebut sebagai production frontier, atau batas output potensial/ maksimal yang dapat dicapai perusahaan melalui input dan teknologi yang tersedia. Dengan kondisi ini, maka perusahaan akan sulit mencapai kondisi efisien secara teknis, padahal hal ini menjadi faktor penting dalam stabilitas produksi (Samad dan Patwari, 2002).

Dalam kaitannya dengan strategi perusahaan, kemitraan merupakan respon untuk mengatasi permasalahan, salah satunya dengan menciptakan konsolidasi yang memberikan manfaat bagi IMK. Konsolidasi terjadi baik dalam proses produksi, peningkatan nilai tawar, akses pada informasi pasar, maupun pengetahuan yang dapat mengubah kebijakan dan metode produksi. Dengan konsolidasi, kemitraan juga memberikan kesempatan bagi IMK menjadi bagian dari organisasi "besar" dan menikmati berbagai manfaat yang biasa diperoleh industri besar (Loveman dan Sengenberger, 1991; Marino et al, 2008). Hal yang sama juga diungkapkan Pyke dan Sengenberger (1992) bahwa kemitraan adalah pencapaian dari "economic of scale", dan Schmitz (1999) serta Berry (1997) menyebutnya sebagai pencapaian "collective efficiency". Melalui kemitraan, perusahaan memperoleh cara yang fleksibel dan cepat dalam mengakses sumberdaya dan keterampilan tambahan yang dimiliki perusahaan lain karena memungkinkan sekelompok perusahaan untuk membuat pengaturan, pertukaran, penggunaan, dan pengembangan teknologi dan jasa-jasa (Genc dan lyigun, 2011).

Selain penting bagi perusahaan, relevansi penerapan konsep efisiensi teknis pada IMK di Indonesia secara umum juga terkait dengan pengendalian produksi yang mutlak dilakukan untuk membawa keuntungan usaha (Nadvi, 1995). Berbeda dengan dengan Industri 
Menengah dan Besar (IMB), IMK lebih banyak mempekerjakan tenaga kerja non terampil dan pemanfaatan sebagian besar sumberdaya lokal. Implikasi dari hal ini adalah terciptanya banyak tenaga kerja dengan kemampuan rendah dan awam terhadap teknologi, yang membuat tingkat efisiensi teknis rendah (Raj, 2007). Pilihan untuk meningkatkan teknologi melalui perluasan kapital bukan merupakan solusi yang mudah karena terbatasnya modal. Maka, jalan keluar terbaik adalah dengan mengusahakan efisiensi teknis secara internal (Schmitz, 1982; Taymaz, 2005) melalui perbaikan pengelolaan proses produksi.

Penelitian yang melihat langsung kaitan kemitraan dalam prediksi efiensi teknis sejauh yang diketahui penulis belum pernah dilakukan. Penelitian efisiensi teknis yang tersedia di Indonesia, seperti Pitt dan Lee (1981), Hill dan Kalirajan (1993), serta Margono dan Sharma (2006) hanya terbatas pada prediksi nilai efisiensi teknis dan faktor-faktor spesifik perusahaan yang mempengaruhinya, seperti usia usaha, skala usaha, struktur tenaga kerja, tingkat pendidikan pengelola usaha, dan struktur permodalan. Sejalan dengan itu, maka diperlukan spesifikasi empiris yang dapat digunakan untuk melihat hubungan antara kemitraan terhadap efisiensi teknis. Spesifikasi empiris diadopsi dari beberapa sumber literatur untuk menyesuaikan dengan kondisi dan data IMK yang tersedia di Indonesia. Demikian juga, pengukuran kemitraan di Portugis sebagai variabel utama juga memberikan tantangan tersendiri karena belum pernah diukur dengan data yang besar di Indonesia. Pengukuran kemitraan yang ada sejauh ini dilakukan menurut data survei dan masing-masing memiliki pendekatan tersendiri. Hayashi (2001) dalam penelitiannya mengenai peran kemitraan dengan pola sub-kontrak, terhadap produktivitas perusahaan, mengukur kemitraan pada industri permesinan dan metal di Indonesia dengan menghitung tingkat kemitraan melalui persentase penjualan produk perusahaan kepada mitra. Berbeda dengan Hayashi, Franco dan Haase (2015) membuat taksonomi kemitraan berdasarkan indeks yang menentukan posisi perusahaan yang direpresentasikan melalui dimensi-dimensi pembentuk kemitraan, yaitu motif/ dorongan perusahaan untuk bermitra, kepercayaan (trust) dalam kemitraan, dan komitmen dalam kemitraan dan kesuksesan kemitraan. Maka, penelitian ini merupakan penelitian pertama dan awal yang akan menganalisis korelasi kemitraan terhadap efisiensi teknis IMK di Indonesia, sekaligus berkontribusi pada pengukuran kemitraan yang belum pernah ada di Indonesia sebelumnya.

\section{Tinjauan Literatur}

Penting untuk memahami efisiensi teknis sebagai dasar dari model fungsi produksi yang akan digunakan dalam estimasi model empiris. Konsep mengenai efisiensi teknis pertama kali diperkenalkan oleh Farrel (1957) yang berhasil menjelaskan bagaimana suatu perusahaan dapat mencapai production frontier atau output potensial perusahaan dengan input dan teknologi yang tersedia. Perusahaan yang telah berhasil mencapai output potensial, dikatakan sebagai perusahaan yang efisien secara teknis. Selanjutnya, Aigner et al (1977) dan Meeusen dan van den Broeck (1977) mengembangkan cara pengukuran production frontier secara stokastik dengan model umum sebagai berikut:

$$
y_{i}^{*}=f_{i}\left(x_{1}, x_{2}, \ldots, x_{m}\right) \exp \left(w_{i}\right)
$$

Model fungsi produksi diatas menunjukkan bahwa output potensial $\left(\mathrm{y}_{\mathrm{i}}^{*}\right)$ ditentukan oleh input $\left(\mathrm{x}_{\mathrm{i}}\right)$ dan faktor lainnya (disturbance) yang menimbulkan variasi output diantara perusahaan, sekaligus menunjukkan residual dari model tersebut. Perusahaan yang berproduksi tidak pada frontier atau dibawah frontier, dikatakan sebagai tidak efisien secara teknis atau inefisien secara teknis. Hal ini dapat disebabkan oleh beberapa faktor spesifik perusahaan yang tidak masuk di dalam model, tetapi direpresentasikan oleh variabel $w_{i}$ dalam persamaan 2 . Variabel $w_{i}$ sendiri terbagi menjadi dua, pertama adalah yang mempengaruhi efisiensi teknis (TE), atau biasa diproksi sebagai inefisiensi teknis $\left(u_{i}\right)$, dan yang kedua merupakan random error $\left(\mathrm{v}_{\mathrm{i}}\right)$, sehingga persamaan 1 dapat dituliskan kembali menjadi:

$$
y_{i}^{*}=f_{i}\left(x_{1}, x_{2}, \ldots, x_{m}\right) \exp \left(u_{i}-v_{i}\right)
$$


Inefisiensi teknis atau $u_{i}$ bersifat non-negatif dan bernilai antara nol dan satu. Artinya, jika $u_{i}$ bernilai nol maka tidak terjadi inefisiensi teknis atau dengan kata lain, perusahaan sudah efisien secara teknis. Sebaliknya, jika $u_{i}$ bernilai satu maka terjadi inefisiensi teknis penuh atau perusahaan tidak efisien secara teknis. Maka efisiensi teknis (TE) merupakan eksponensial dari inefisiensi teknis $\left(\mathrm{u}_{\mathrm{i}}\right)$.

Dalam model fungsi produksi, inefisiensi teknis $\left(u_{i}\right)$ digunakan sebagai proksi dari efisiensi teknis (TE). Maka, selanjutnya faktor-faktor yang mempengaruhi inefisiensi teknis $\left(\mathrm{u}_{\mathrm{i}}\right)$ dituliskan sebagai:

$$
u_{i}=\delta_{0}+\delta_{1} z_{1 i}+\delta_{2} z_{2 i}+\delta_{3} z_{3 i}+\cdots+\delta_{n} z_{n i}+e_{i}
$$

Dimana $\mathrm{z}_{1 i}, \mathrm{z}_{2 i}, \mathrm{z}_{3 i}, \ldots, \mathrm{z}_{\mathrm{ni}}$ adalah varibel penjelas sebanyak $\mathrm{n}$ yang diduga menjadi faktor spesifik perusahaan yang berkontribusi pada inefisiensi teknis. Selanjutnya, $\delta_{1}, \delta_{2}, \delta_{3^{\prime}} \ldots$, $\delta_{n}$ adalah koefisien yang akan diestimasi pada masing-masing parameter $z_{n i}$ dan $e_{i}$ adalah random error. Aplikasi model ini dapat dilakukan kedalam penelitian empiris setelah dimodifikasi sesuai kepentingan.

Korelasi kemitraan dan efisiensi teknis perusahaan memang belum tersedia studi teoritisnya. Namun, hubungan keduanya dapat dilihat dari landasan yang sama, yaitu adanya permasalahan keterbatasan sumberdaya produksi yang umum dihadapi IMK dan upaya IMK dalam mengatasinya. Banyak faktor yang menentukan suatu IMK dapat bertahan didalam industri. Barrier to entry merupakan salah satu kendala awal yang menjegal IMK untuk masuk kedalam industri. Selanjutnya, selama proses berusaha, ada "survival probability" yang menentukan kemungkinan suatu IMK akan mampu bertahan atau mati/ keluar (exit) dari industri. Taymaz (2005) berpendapat kemampuan IMK bertahan menunjukkan adanya perkembangan kinerja perusahaan seiring adanya penyesuaian skala optimalisasi sejalan dengan bertambahnya skala usaha. Dengan kata lain, IMK yang dapat bertahan dianggap sudah produktif, dimana efisiensi teknis menjadi salah satu ukuran didalamnya. Pendapat ini juga diperkuat oleh Jovanovic (1982) yang mengasumsikan perusahaan yang berkembang dan bertahan dalam industri adalah perusahaan yang efisien.

Prediksi efisiensi menjadi penting untuk memahami sejauh mana kontribusinya bagi perusahaan sebagai prasyarat untuk mengakses kebutuhan dan dukungan dalam usaha (Essien dan Bello, 2007). Efisiensi teknis yang bergerak keatas (shifting upward) dalam kurva fungsi produksi sebagai penanda adanya perbaikan efisiensi teknis pada perusahaan dapat terjadi akibat dua hal. Pertama adalah alokasi intersektoral sumberdaya produksi menuju penggunaan input terendah, dan yang kedua adalah akibat dari adanya perbaikan praktik terbaik atau metode produksi dalam penggunaan teknologi oleh perusahaan. Pencapaian output potensial, dengan demikian mutlak dilakukan sebagai pengendalian atas produksi yang akan membawa keuntungan usaha (Nadvi, 1995). Bertolak belakang dengan Industri Menengah dan Besar (IMB) yang dapat mencapai tingkat efisiensi teknis tinggi dengan banyak cara, seperti penambahan input produksi berupa kapital, IMK tidak punya banyak opsi selain mengelola input yang tersedia bermula dengan mengandalkan usahanya sendiri.

Kemitraan merupakan salah satu jalan bagi IMK untuk menghadapi berbagai tantangan usaha yang dijelaskan diatas. Sebagai pengembangan dari hubungan jangka panjang yang stabil antar perusahaan, relasi kemitraan sangat penting bagi IMK. Kolaborasi ini memungkinkan IMK memperoleh tambahan kapasitas dari IMB maupun sesama IMK untuk menekan biaya produksi (Tambunan, 2007), diantaranya melalui spesialisasi, tanpa perlu menambah permodalan yang besar untuk membeli peralatan produksi misalnya. Ini dimungkinkan karena berbagi peralatan produksi dan berbagi pesanan diantara IMK menjadi salah satu perwujudan kemitraan yang banyak dilakukan (Schmitz, 2007).

Selain itu, pekerjaan jasa, seperti desain, riset pasar, periklanan, penjualan dan distribusi, keuangan, pelatihan staf, dan pembelian bahan baku menjadi lebih efisien karena disediakan secara kolektif. Kemitraan yang terbentuk antara pembeli dan penjual, misalnya, dapat memfasilitasi peluang bisnis melalui peningkatan kapabilitas perusahaan (Nichter dan Goldmark, 2009), selain juga dapat memitigasi risiko perubahan pasar (shock). Perjanjian dengan pembeli dapat mengurangi risiko dan biaya untuk masuk ke dalam pasar baru melalui garansi dan informasi mengenai kebutuhan pasar, bahkan juga mengurangi investasi kapital. 
Selain manfaat di atas, secara "intangible" kemitraan memfasilitasi terjadinya peningkatan teknologi yang tidak terbatas pada permesinan, tapi juga meliputi perbaikan dalam organisasi pekerjaan, penanganan inventory, dan desain produk yang hadir dari berbagai mekanisme (Berry et al, 2001). Beberapa studi seperti Berry (1997), Tambunan (1997), Essien dan Bello (2007) dan Taymaz (2005) telah mengidentifikasi "sharing of knowledge", yang meliputi teknologi know-how, kemampuan organisasi, informasi pasar, pembagian kerja, dan spesialisasi pekerjaan, sebagai manfaat diantara perusahaan yang bermitra. Melalui saluran ini, perusahaan saling mengakses "stock of knowledge" untuk melengkapi pengetahuan atau spesialisasi yang sudah ada. Juga memberikan kesempatan pada IMK yang belum mampu melakukan investasi untuk riset dan pengembangan produk, serta membeli mesin dengan teknologi yang maju (advance), untuk mengetahui praktik teknik produksi terbaik. Hal ini dapat terwujud dengan tersedianya peluang belajar dan inovasi, seperti dalam hal kualitas produk, perawatan, dan isu-isu teknis lainnya. Maka, dengan diperolehnya pengetahuan sebagai faktor yang dapat memperbaiki teknik perusahaan dalam produksi, diharapkan efisiensi teknis dapat dicapai.

Gambaran hubungan antara kemitraan dan efisiensi teknis disajikan pada Gambar 1. Disini ditunjukkan bahwa teknologi memungkinkan pergeseran tingkat efisiensi teknis semakin dekat pada production frontier (Hill dan Kalirajan, 2007). Pada kondisi permulaan, IMK yang memiliki satu input ( $\mathrm{x}$ ) dan memproduksi satu output $(\mathrm{y})$ digambarkan memiliki tingkat efisiensi teknis pada titik $A$ atau berada di bawah garis OF yang merupakan production frontier perusahaan. Titik A menunjukkan kondisi yang belum efisiens secara teknis. Perbaikan tingkat efisiensi teknis pada industri makanan dapat dilakukan misalnya melalui perbaikan teknik pengemasan produk dengan lebih cepat sehingga mampu menghasilkan output yang lebih banyak dari sejumlah y' menjadi y". Maka, efisiensi teknis perusahaan akan bergerak dari titik A menuju titik B yang menunjukkan tingkat efisiensi teknis yang lebih baik.

Pergerakan tingkat efisiensi teknis dari titik $A$ ke titik $C$ juga menggambarkan perbaikan efisiensi teknis melalui pengurangan nilai input dengan tetap menghasilkan jumlah output yang sama. Misalnya, kemitraan melalui penggunaan mesin produksi secara kolektif dapat mengurangi beban biaya akuisisi kapital sekaligus mempercepat produksi melalui pengetahuan praktik produksi dengan teknologi terbaru. Maka, dengan input yang berkurang dari x" ke x', dapat diperoleh hasil output yang sama yaitu y'.

Gambar 1. Kurva hubungan kemitraan dan efisiensi teknis

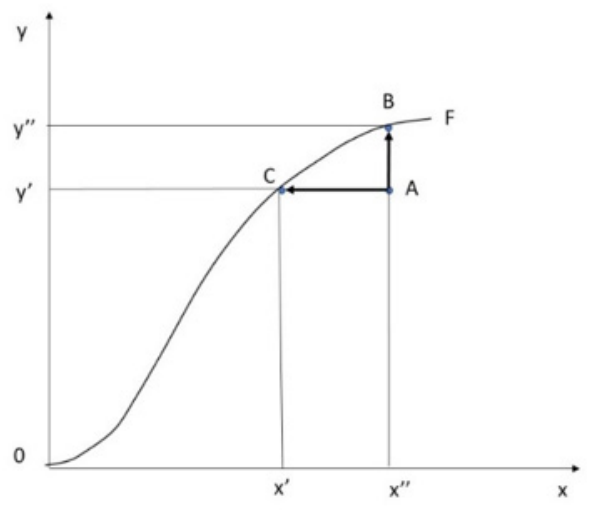

Sumber: diolah dari Coelli et al (2005)

Studi efisiensi teknis di Indonesia yang relevan sebagai acuan penelitian adalah Hill dan Kalirajan (1993) yang melakukan studi yang serupa pada industri kecil garmen dan melihat perbedaan faktor spesifik perusahaan pada perusahaan dengan efisiensi teknis tinggi dan perusahaan dengan efisiensi teknis rendah. Disini disimpulkan bahwa tingkat efisiensi teknis tinggi (diatas 75 persen) memiliki kaitan erat dengan orientasi ekspor, partisipasi tenaga kerja perempuan, dan integrasi finansial. Rata-rata efisiensi teknis pada industri garmen ini ditemukan sebesar 62,6 persen, atau tidak berbeda jauh dengan studi Pitt dan Lee (1981). 
Selanjutnya, tahun 2006 Margono dan Sharma melakukan penelitian serupa di sektor makanan, tekstil, kimia, dan metal pada industri kecil dan besar di Indonesia. Faktor spesifik perusahaan yang diidentifikasi berkontribusi pada inefisiensi teknis perusahaan adalah lokasi perusahaan, kepemilikan usaha (publik atau privat), dan maturitas perusahaan yang direpresentasikan melalui usia usaha. Dengan estimasi model menggunakan maximum likelihood, hasil yang ditemukan bervariasi dengan rata-rata tingkat efisiensi pada keempat sektor sebesar 55,87 persen, atau masih dapat diperbandingkan dengan dua studi sebelumnya.

Ada pula Charoenrat et al (2013) yang melakukan studi efisiensi teknis pada industri manufaktur kecil di Thailand dan menemukan skala usaha, usia usaha, tenaga kerja terampil, karakteristik kepemilikan usaha, dan lokasi sebagai faktor spesifik perusahaan yang mempengaruhi efisiensi teknis. Hasil yang ditemukan pun bervariasi di antara sektor. Skala usaha pada sebagian besar sektor menunjukkan hubungan yang positif dengan efisiensi teknis dimana perusahaan yang lebih besar dianggap memiliki kemampuan dan kecepatan memperoleh teknologi dibandingkan perusahaan yang lebih kecil. Usia usaha menunjukkan hubungan yang bervariasi dengan efisiensi teknis, dimana hubungan positif menunjukkan perusahaan yang lebih tua memiliki lebih banyak pengalaman untuk belajar dari kesalahan (learning by doing) dan memanifestasikannya dalam perbaikan efisiensi teknis, sedangkan hubungan negatif dapat merupakan "ekses" dari proses belajar yang berdampak pada teknologi yang kadaluwarsa dibandingkan dengan perusahaan yang lebih muda. Tenaga kerja terampil yang direpresentasikan dengan rasio tenaga kerja terampil per total tenaga kerja pada sembilan sektor yang diobservasi menunjukkan hubungan yang positif dengan efisiensi teknis. Kedekatan lokasi usaha dengan ibukota ditemukan memberikan efek positif pada efisiensi teknis karena kedekatan dengan pusat ekonomi memudahkan berbagai akses usaha.

Selanjutnya, kemitraan sebagai variabel utama penelitian dipahami sebagai hal yang memiliki definisi dan terminologi yang sangat luas karena belum sepenuhnya dimengerti dan disepakati para peneliti (Schmitz, 2007; Hanna dan Walsh, 2008). Definisi dan terminologi kemitraan dapat disamakan dan saling digantikan diantaranya dengan interfirm cooperation, alliance, strategic alliance, cooperative venture dan firm network. Kemitraan juga dapat dilakukan secara vertikal dengan pihak yang memiliki kedudukan berbeda dalam rantai nilai, ataupun secara horizontal, yaitu di antara usaha yang sama. Maka, diperlukan rujukan pada studi mengenai pengukuran kemitraan sebelumnya untuk mendapatkan ukuran kemitraan yang sesuai. Pengukuran kemitraan sebagai indeks dilakukan oleh Hayashi (2001) pada industri kecil dan menengah pada tahun 1993, 1996, dan 1998 di Indonesia untuk melihat perannya dalam produktivitas. Di sini pola sub-kontrak, salah satu subset dari kemitraaan, dihitung melalui persentase penjualan produk perusahaan kepada mitra terhadap total turnover. Selanjutnya, studi Franco dan Haase (2015) menggunakan teknik Principal Component Analysis (PCA) mencoba menjelaskan taksonomi kemitraan (interfirm alliances) pada usaha kecil dan menengah juga melalui indeks. Melalui studi cross sectional, survei dilakukan pada lebih dari 100 perusahaan bermitra dan melibatkan beberapa set variabel dan dimensi seperti pendorong kemitraan, tujuan kemitraan, pemilihan mitra usaha, dan faktor kesuksesan kemitraan, pada perusahaan kecil dan menegah di Portugal. Data diperoleh melalui kuesioner yang diberikan kepada manajer perusahaan yang berpengalaman dalam kemitraan. Pertanyaan-pertanyaan dikelompokkan menurut dimensinya dengan menggunakan skala dengan lima kategori ( $1=$ " tidak penting" sampai $5=$ " paling penting") dan selanjutnya dilakukan Principal Component Analysis (PCA) pada masing-masing dimensi.

Penggunaan teknik analisis multivariat untuk mengukur kemitraan dinilai penulis menjadi cara yang paling relevan digunakan karena mengakomodir banyaknya aspek, dimensi, serta pengertian yang bervariasi mengenai kemitraan di tengah ketiadaan data ideal. Penggunaan teknik ini mampu merpresentasikan esensi dari keragaman informasi yang menggambarkan kemitraan pada data Survei Industri Mikro dan Kecil di Indonesia. Penggunaan teknik ini diperkuat dengan Filmer dan Prichett pada tahun 2001 yang menggunakan PCA dalam penelitian social dan ekonomi yaitu pengukuran kekayaan rumah tangga melalui data aset. 


\section{Metode Penelitian}

Penelitian ini dilakukan dalam beberapa alur, pertama melalui perhitungan fungsi produksi perusahaan, pengukuran variabel kemitraan, dan estimasi hubungan keduanya melalui metode maximum likelihood. Di bawah ini diuraikan dua persamaan yang masingmasing menunjukkan model fungsi produksi perusahaan (persamaan 4) dan faktor spesifik perusahaan yang mempengaruhi inefisiensi teknis yang merupakan proksi dari efisiensi teknis, dimana efisiensi teknis adalah negatif eksponensial dari inefisiensi teknis (persamaan 5).

$$
\begin{aligned}
\ln y_{i}=\beta_{0}+ & \beta_{k} \ln K_{i}+\beta_{l} \ln L_{i} \\
& +\beta_{m} \ln M_{i}+\frac{1}{2}\left[\beta_{K K}\left(\ln K_{i}\right)^{2}+\beta_{L L}\left(\ln L_{i}\right)^{2}+\beta_{M M}\left(\ln M_{i}\right)^{2}\right] \\
& +\beta_{K L} \ln K_{i} \ln L_{i}+\beta_{K M} \ln K_{i} \ln M_{i}+\beta_{L M} \ln L_{i} \ln M_{i}+v_{i}-u_{i}
\end{aligned}
$$

Pertama, In $\mathrm{y}_{\mathrm{i}}$ adalah logaritma natural dari output perusahaan yang dihitung dari nilai produksi kotor pada periode observasi atau bulan terakhir berproduksi; In $\left(\mathrm{K}_{\mathrm{i}}\right)$ adalah logaritma natural dari nilai kapital perusahaan i yang dihitung sebagai akumulasi nilai buku dari tanah, bangunan/gedung, mesin dan perlengkapan, dan kendaraan; In $\left(\mathrm{L}_{\mathrm{i}}\right)$ adalah logaritma natural dari jumlah tenaga kerja perusahaan i yang dihitung sebagai jumlah orang yang bekerja, baik yang dibayar, maupun tidak dibayar; In $\left(\mathrm{M}_{\mathrm{i}}\right)$ adalah logaritma natural dari nilai material perusahaan i yang dihitung sebagai konsumsi bahan baku dan energi yang terdiri dari pemakaian pelumas dan bahan bakar, pemakaian listrik, dan pemakaian air;

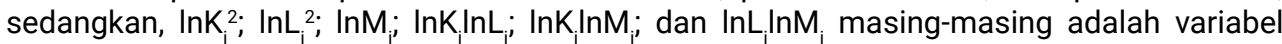
yang menunjukkan interaksi antara variabel input pada perusahaan $\mathrm{i}$. $\mathrm{v}_{\mathrm{i}}$ adalah random error; dan $u_{i}$ adalah inefisiensi teknis perusahaan. Selanjutnya, persamaan 5 menguraikan faktorfaktor yang mempengaruhi inefisiensi perusahaan sebagai proksi dari efisiensi teknis dengan spesifikasi sebagai berikut:

$$
\begin{aligned}
u_{i}= & \delta_{0}+\delta_{1} \text { Kemitraan }_{i}+\delta_{2} \text { Usia }_{i}+\delta_{3} \text { Modalluar }_{i}+\delta_{4} \text { Perempuan }_{i}+ \\
& \delta_{5} \text { NonUpah }_{i}+\delta_{6} \text { NakerProd }+\delta_{7} \text { Sex }_{i}+\delta_{8} \text { Edukasi }_{i}+\delta_{9} \text { Lokasi }_{i}+ \\
& \delta_{10} \text { Sektor }+e
\end{aligned}
$$

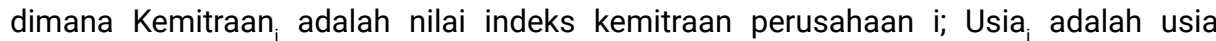
perusahaan i dalam tahun; Modalluar, adalah proporsi modal luar perusahaan i bernilai 1 jika modal luar lebih dari 50 persen dari total modal, dan bernilai 0 jika lainnya; Perempuan adalah proporsi tenaga kerja perempuan dari total tenaga kerja dalam perusahaan i; NonUpah adalah proporsi tenaga kerja tidak dibayar dari jumlah total tenaga kerja; NakerProd adalah proporsi tenaga kerja produksi dari total tenaga kerja dalam perusahaan i; Sex adalah jenis kelamin pemilik usaha bernilai 1 jika laki-laki, dan 0 jika perempuan; Edukasi, adalah lama bersekolah pemilik perusahaan i dalam tahun; Lokasi ${ }_{i}$ adalah lokasi perusahaan i menurut klasifikasi perkotaan dan perdesaan BPS, bernilai 1 jika terletak di wilayah perkotaan, dan bernilai 0 bila di perdesaan; dan sektor adalah jenis kegiatan usaha perusahaan i bernilai 1 jika bergerak di sektor Non makanan, dan bernilai 0 jika bergerak di sektor makanan (termasuk minuman).

Selanjutnya, variabel-variabel penjelas dalam model efisiensi teknis dapat dijelaskan sebagai berikut. Usia usaha menggambarkan akumulasi learning by doing perusahaan. Perusahaan yang lebih lama berdiri memperoleh lebih banyak pengalaman yang termanifestasi dalam perkembangan perusahaan yang positif (Admassie dan Matambalya, 2002; Batra dan Tan, 2003; Phan, 2004, Tran et al., 2008, Pitt dan Lee, 1981) dan menunjukkan perusahaan yang produktif karena mampu bertahan dalam industri. Di sisi lain, perusahaan yang lebih muda juga dapat memberikan efek positif pada efisiensi teknis karena memiliki kesempatan lebih besar untuk memperoleh teknologi termutakhir sehingga mampu mengakselerasi produksi (Phan, 2004). Modal luar dalam penelitian ini digunakan untuk menunjukkan persentase 
modal luar dalam perusahaan. Perusahaan yang sudah mendekati frontier dianggap lebih berani dan mampu untuk melakukan pinjaman (Hill dan Kalirajan, 1993). Maka, modal luar diduga berhubungan positif dengan efisiensi teknis dimana perusahaan dengan persentase modal luar yang lebih besar cenderung lebih efisien secara teknis.

Tenaga kerja perempuan dibanyak negara berkembang menjadi mayoritas tenaga kerja di sektor informal. Sektor informal yang banyak diduduki IMK menawarkan kemudahan bagi perempuan untuk masuk ke dalam pasar tenaga kerja. Secara antropologi, perempuan juga diasosiasikan sebagai individu yang produktif. Namun, disisi lain perempuan sering mengalami keterbatasan mobilitas dan hambatan dalam menyeimbangkan tugas domestik dan pekerjaan, sehingga tenaga kerja perempuan dianggap kurang produktif. (Nichter dan Goldmark, 2007; Hill dan Kalirajan, 1993)

Hubungan tenaga kerja tidak dibayar dan efisiensi teknis pada perusahaan tersedia dalam dua pandangan yang berbeda. Tenaga kerja tidak dibayar dapat menggambarkan fleksibilitas dan kemampuan daya saing yang lebih tinggi menurut model perilaku rumah tangga (Singh et al, 1986); namun disisi lain, hal ini bisa jadi pilihan terakhir perusahaan untuk bertahan dari kebangkrutan (Hill dan Kalirajan, 1993). Dengan demikian, hubungan keduanya masih bersifat ambigu. Tenaga kerja produksi digunakan sebagai proksi dari tenaga kerja terampil (skilled worker). Tenaga kerja produksi berhubungan positif dengan efisiensi teknis karena menggambarkan produktivitas dan spesialisasi dalam proses produksi yang lebih baik. (Hill dan Kalirajan, 1993)

Edukasi pemilik usaha merupakan proksi dari pendidikan pengelola usaha. Pendidikan yang rendah dianggap sebagai ketidakmampuan dalam pengelolaan usaha (Alvarez dan Crespi, 2001), sebaliknya pendidikan yang lebih tinggi memberikan kesempatan bagi pemilik usaha untuk mengembangkan kapasitas dalam mempelajari proses produksi baru, desain produk, atau kemampuan teknis spesifik lainnya (Nichter dan Goldmark, 2009). Beberapa bukti empiris juga telah menunjukkan bahwa perusahaan dengan pengelola usaha yang memiliki edukasi lebih tinggi menghasilkan usaha yang lebih efisien (Burki dan Terrel, 1998; Tan dan Batra, 1995). Maka hubungan pendidikan dan efisiensi teknis diduga bernilai positif.

Lokasi usaha menjadi salah satu faktor spesifik perusahaan yang mempengaruhi efisiensi teknis perusahaan. Perusahaan yang berlokasi di perkotaan yang merepresentasikan pusat-pusat ekonomi dinilai lebih efisien dibandingkan dengan perusahaan yang terletak di wilayah perdesaan atau jauh dari pusat ekonomi. Kedekataan lokasi dengan pusat aktivitas ekonomi dianggap memberikan akses yang lebih mudah, baik ketersediaan tenaga kerja dengan pendidikan lebih baik dan kesempatan pasar yang lebih baik (Charoenrat, 2013; Hill dan Kalirajan, 1993).

Sektor usaha menjadi variabel yang menjadi konsideran dalam berbagai studi produktivitas, seperti Margono dan Sharma (2006), Hayashi (2001); Burki dan Terrel (1998), untuk melihat apakah sektor yang berbeda mempengaruhi tngkat efisiensi teknis yang berbeda pula. Margono dan Sharma, misalnya, membagi industri menjadi sektor makanan, tekstil, kimia, dan produk metal dan hasilnya menunjukkan bahwa sektor yang berbeda memiliki karakteristik produksi yang berbeda ditunjukkan dengan signifikansi hubungan variabel penjelas dan efisiensi teknis yang menghasilkan arah yang berbeda pada tiap sektor. Contohnya, efek lama usaha pada sektor makanan dan tekstil terbukti tidak signifikan secara statistik. Sedangkan, pada sektor kimia dan produk metal terbukti signifikan walaupun memiliki arah yang berlawanan. Dalam penelitian ini, sektor industri hanya dibagi menjadi dua, yaitu sektor makanan (termasuk minuman) dan sektor non makanan karena terbatasnya jumlah sampel. Sektor makanan merupakan sektor yang mendominasi jumlah sampel baik pada industri mikro dan industri kecil dan dianggap memiliki penggunaan teknologi produksi yang lebih sederhana dibandingkan sektor non makanan.

Jenis kelamin pemilik usaha dipertimbangkan sebagai faktor yang mempengaruhi efisiensi teknis perusahaan karena beberapa pendapat yang menyatakan bahwa perempuan lebih tidak diuntungkan dibandingkan laki-laki dalam pengelolaan usaha. Seperti disampaikan Bardasi dan Sabarwal (2001), perempuan cenderung berada pada usaha dengan skala yang lebih kecil daripada laki-laki, walaupun kesenjangan dari sisi efisiensi dan pertumbuhan usaha tidak terlalu besar. Sedangkan menurut Fischer dan Dyke (1993), perempuan lebih sering menerima diskriminasi misalnya dalam hal edukasi sampai dengan akses keuangan yang menghambat usaha sehingga menimbulkan efisiensi teknis yang lebih rendah dibandingkan 
laki-laki.

Kemitraan sebagai variabel utama dihitung melalui teknik PCA untuk menyederhanakan data kemitraan yang banyak tanpa kehilangan esensi atau informasi penting. Langkah pertama adalah melakukan normalisasi data dengan persamaan berikut,

$$
a_{i j}=\frac{\left(a_{1 j-}^{*} a_{1}^{*}\right)}{s_{1}^{*}},
$$

dimana $\mathrm{a}_{1}$ * adalah mean dari $\mathrm{a}_{1 j}$ * pada seluruh perusahaan dan $\mathrm{s}_{1}$ * adalah standar deviasinya. Variabel-variabel ini disajikan dalam kombinasi linear dari sekumpulan komponen yang mendasari masing-masing perusahaan j:

$$
\begin{aligned}
& a_{i j}=v_{11} A_{1 j}+v_{12} A_{2 j}+\cdots+v_{1 N} A_{N j} \\
& \cdots \\
& a_{N j}=v_{N 1} A_{1 j}+v_{N 2} A_{2 j}+\cdots+v_{N N} A_{N j} \quad j=1, \ldots, J
\end{aligned}
$$

A adalah komponen dan $v$ adalah koefisien dari setiap komponen untuk setiap sub variabel kemitraan. PCA menemukan kombinasi linear dari variabel-variabel yang memiliki varians maksimal, sebagai first principal component (PC1). Prosedur ini memecahkan persamaan $\left(R=\lambda_{n}\right) v_{n}=0$ untuk $\lambda_{n}$ dan $v_{n^{\prime}}$ dimana $R$ adalah matriks korelasi antara variabel terhitung (a) dan $v_{n}$ merupakan vector dari koefisien pada komponen ke-n pada setiap variabel. Penyelesaian persamaan ini menghasilkan $\lambda_{n}$ (dikenal sebagai eigenvalues) dan eigenvector, $v_{n}$. Estimasi terakhir dihasilkan dengan mengalikan $v_{n}$ sehingga jumlah dari akarnya merupakan penjumlahan dari total varians.

Selanjutnya, scoring factors diperoleh dengan membalikkan (inverting) persamaan 7, dan menghasilkan sekumpulan estimasi untuk setiap $\mathrm{N}$ dalam principal component:

$$
\begin{aligned}
& A_{i j}=f_{11} a_{1 j}+f_{12} a_{2 j}+\cdots+f_{1 N} a_{N j} \\
& \cdots \\
& A_{N j}=f_{N 1} a_{1 j}+f_{N 2} a_{2 j}+\cdots+f_{N N} a_{N j} \quad j=1, \ldots, J
\end{aligned}
$$

Indeks kemitraan untuk masing-masing perusahaan diperoleh dengan mengalikan bobot dengan nilai normalisasi data dan menjumlahkan seluruh komponennya menurut persamaan:

$$
A_{i j}=f_{11}\left(\frac{a_{1 j-}^{*} a_{1}^{*}}{s_{1}^{*}}\right)+\cdots+f_{1 N}\left(\frac{a_{N j-}^{*} a_{N}^{*}}{s_{1}^{*}}\right)
$$


Tabel 1. Sub variabel kemitraan menurut jenis sumberdaya yang dikerjasamakan

\begin{tabular}{|c|c|c|}
\hline No. & Jenis Kemitraan & Nilai \\
\hline 1 & $\begin{array}{l}\text { Kemitraan dalam hal Uang (U) } \\
\text { (meliputi kerjasama dalam hal permodalan usaha) }\end{array}$ & $\begin{array}{l}0=\text { Tidak } \\
1=Y a\end{array}$ \\
\hline 2 & $\begin{array}{l}\text { Kemitraan dalam hal Bahan baku }(B) \\
\text { (meliputi kerjasama dalam hal pengadaan bahan mentah sampai } \\
\text { bahan setengah jadi) }\end{array}$ & $\begin{array}{l}0=\text { Tidak } \\
1=Y a\end{array}$ \\
\hline 3 & $\begin{array}{l}\text { Kemitraan dalam hal Pemasaran }(P) \\
\text { (meliputi kerjasama dalam hal tenaga kerja untuk pemasaran, } \\
\text { termasuk distribusi produk dan makloon) }\end{array}$ & $\begin{array}{l}0=\text { Tidak } \\
1=Y a\end{array}$ \\
\hline 4 & $\begin{array}{l}\text { Kemitraan dalam hal Mesin }(\mathrm{M}) \\
\text { (meliputi kerjasama dalam hal alat/ sistem yang kompleks, yang } \\
\text { dapat mengubah bentuk bahan mentah dan bahan setengah jadi, } \\
\text { sampai menjadi bahan jadi) }\end{array}$ & $\begin{array}{l}0=\text { Tidak } \\
1=Y a\end{array}$ \\
\hline 5 & $\begin{array}{l}\text { Kemitraan dalam hal Barang modal/ Peralatan }(A) \\
\text { (meliputi kerjasama dalam hal alat/sistem sederhana yang mem- } \\
\text { bantu dalam proses produksi barang mentah, bahan setengah } \\
\text { jadi, sampai dengan bahan jadi) }\end{array}$ & $\begin{array}{l}0=\text { Tidak } \\
1=\text { Ya }\end{array}$ \\
\hline
\end{tabular}

Sumber: Survei Industri Mikro dan Kecil Tahunan 2014 dan Pedoman Pencacah Survei Industri Mikro dan Kecil Tahunan 2014, BPS (telah diolah kembali) 
Variabel kemitraan dibangun dari sub variabel kemitraan yang tersedia dalam Survei Industri Mikro dan Kecil Tahunan yang masing-masing menunjukkan pernyataan perusahaan apakah telah menjalin kemitraan pada bidang sumberdaya tertentu. Kelima sub variabel tersebut adalah 1) kemitraan uang, 2) kemitraan bahan baku, 3) kemitraan pemasaran, 4) kemitraan permesinan, dan 5) kemitraan barang modal/ peralatan (Tabel 1). Nilai satu (1) menunjukkan perusahaan yang menyatakan melakukan kemitraan dalam bidang dimaksud, dan nilai nol (0) menunjukkan perusahaan yang menyatakan tidak menjalin kemitraan pada bidang dimaksud. Dengan demikian akan diperoleh lima nilai sub variabel ( 0 atau 1 ) untuk setiap perusahaan. Melalui teknik PCA kelima nilai ini diekstraksi menjadi satu buah nilai yang menujukkan indeks kemitraan masing-masing perusahaan.

\section{Hasil Penelitian}

Tabel 2 dibawah ini menunjukkan hasil statistik deskriptif dari variabel-variabel penelitian. Beberapa hal yang cukup berbeda dari kedua kelompok industri yaitu, diantaranya dalam hal tingkat pendidikan dan tenaga kerja. Pada industri mikro, rata-rata lama pendidikan adalah mendekati enam tahun atau ada pada tingkat sekolah dasar, sedangkan pada industri kecil sampai lebih dari delapan tahun atau setingkat sekolah menengah pertama. Dari sisi tenaga kerja, proporsi jumlah tenaga kerja perempuan pada industri mikro menjadi bagian besar (0.53), namun hanya menjadi bagian kecil di industri kecil (0.36). Yang menarik juga adalah bahwa jumlah tenaga kerja tidak dibayar pada industri mikro mencapai 85 persen dari total tenaga kerja. Porsi ini sangat besar bila dibandingkan dengan industri kecil yang hanya mencapai 23 persen saja.

Untuk mendukung analisa, disajikan pula hasil analisis inferensial seperti pada tabel 3. Prediksi efisiensi teknis dilakukan pada masing-masing industri mikro (IM) dan industri kecil (IK) untuk melihat apakah perbedaan skala usaha menghasilkan korelasi kemitraan dan efisiensi teknis yang berbeda pada kedua kelompok industri. Berdasarkan hasil estimasi, korelasi positif ditemukan terjadi pada industri mikro, sedangkan pada industri kecil tidak ditemukan adanya korelasi.

Koefisien kemitraan bernilai positif pada industri mikro $(0,047)$ menunjukkan bahwa kenaikan nilai indeks kemitraan sebanyak 1 unit menunjukkan tingkat efisiensi teknis yang naik sebesar 0,047 . Pada industri mikro, seluruh variabel menunjukkan korelasi yang signifikan terhadap efisiensi teknis. Artinya, kemitraan dan faktor-faktor spesifik perusahaan yang ada memang menjadi faktor utama yang mempengaruhi capaian efisiensi teknis perusahaan. Sebaliknya, pada industri kecil, variabel kemitraan dan banyak dari faktor spesifik ini yang tidak terbukti memiliki hubungan dengan efisiensi teknis. Hal ini mengindikasikan adanya perbedaan karakteristik antara kedua kelompok industri dalam hal-hal yang mempengaruhi tingkat efisiensi perusahaan.

Pada industri mikro, faktor spesifik perusahaan yang memiliki korelasi kuat positif terhadap efisiensi teknis adalah usia usaha, edukasi pemilik usaha, tenaga kerja produksi, wilayah usaha di perkotaan, dan sektor usaha non makanan. Sedangkan pada industri kecil, faktor spesifik yang memberikan efek positif pada efisiensi teknis adalah edukasi pemilik usaha. Maka, efisiensi teknis banyak ditentukan oleh tingkat pendidikan pemilik usaha. Industri kecil secara skala relatif lebih besar dibandingkan dengan industri mikro, sehingga memiliki kemampuan akuisisi kapital dan teknologi yang lebih baik tanpa perlu kerjasama atau bermitra dengan pihak lain. Sebaliknya, kemitraan lebih relevan pada industri mikro karena menjadi pilihan dari sedikit alternatif untuk mengakuisisi sumberdaya produksi, Tingkat pendidikan juga diduga sangat mempengaruhi pengelolaan produksi dimana industri kecil dengan rata-rata tingkat pendidikan pemilik usaha yang lebih tinggi dari industri mikro, memungkinkan pengelolaan usaha dan pemahaman penggunaan teknologi yang lebih baik sehingga mampu membawa pada efisiensi teknis dengan sedikit atau tanpa kerjasama dengan pihak lain. 
Tabel 2. Statistik deskriptif industri mikro dan kecil (IMK) menurut faktor spesifik perusahaan

\begin{tabular}{|c|c|c|c|c|}
\hline \multirow[t]{2}{*}{ Variabel } & \multicolumn{2}{|c|}{ Industri Mikro } & \multicolumn{2}{|c|}{ Industri Kecil } \\
\hline & Mean & $S D$ & Mean & $S D$ \\
\hline \multicolumn{5}{|l|}{ Variabel Kontinyu } \\
\hline Usia usaha (tahun) & 17.48 & 10.57 & 15.22 & 9.44 \\
\hline Usia pemilik usaha (tahun) & 47.59 & 11.25 & 47.02 & 10.05 \\
\hline $\begin{array}{l}\text { Lama pendidikan } \\
\text { pemilik usaha (tahun) }\end{array}$ & 5.97 & 4.18 & 8.30 & 4.47 \\
\hline $\begin{array}{l}\text { Proporsi jumlah tenaga kerja } \\
\text { perempuan dari total tenaga kerja }\end{array}$ & 0.53 & 0.39 & 0.36 & 0.31 \\
\hline $\begin{array}{l}\text { Proporsi jumlah tenaga kerja } \\
\text { produksi dari total tenaga kerja }\end{array}$ & 0.98 & 0.10 & 0.94 & 0.15 \\
\hline $\begin{array}{l}\text { Proporsi jumlah tenaga kerja tidak } \\
\text { dibayar dari total tenaga kerja }\end{array}$ & 0.85 & 0.29 & 0.23 & 0.20 \\
\hline Observasi & \multicolumn{2}{|c|}{22971} & \multicolumn{2}{|c|}{2525} \\
\hline \multirow[t]{2}{*}{ Variabel kategorikal (dummy) } & \multicolumn{4}{|c|}{ Jumlah sampel } \\
\hline & \multicolumn{2}{|c|}{ Industri Mikro } & \multicolumn{2}{|c|}{ Industri Kecil } \\
\hline Jenis kelamin pemilik usaha & $\begin{array}{l}\text { Laki-laki } \\
12.949\end{array}$ & $\begin{array}{c}\text { Perempuan } \\
10.041\end{array}$ & $\begin{array}{l}\text { Laki-laki } \\
2.215\end{array}$ & $\begin{array}{c}\text { Perempuan } \\
310\end{array}$ \\
\hline Proporsi modal luar per total modal & $\begin{array}{l}\text { Lebih dari } \\
50 \% \\
20.495\end{array}$ & $\begin{array}{c}\text { Kurang dari } \\
50 \% \\
2.495\end{array}$ & $\begin{array}{c}\text { Lebih dari } \\
50 \% \\
1.872\end{array}$ & $\begin{array}{c}\text { Kurang dari } \\
50 \% \\
653\end{array}$ \\
\hline Lokasi & $\begin{array}{l}\text { Desa } \\
7209\end{array}$ & $\begin{array}{c}\text { Kota } \\
15781\end{array}$ & $\begin{array}{c}\text { Desa } \\
614\end{array}$ & $\begin{array}{l}\text { Kota } \\
1911\end{array}$ \\
\hline Sektor & $\begin{array}{l}\text { Makanan } \\
8.127\end{array}$ & $\begin{array}{c}\text { Non Makanan } \\
14.863\end{array}$ & $\begin{array}{l}\text { Makanan } \\
559\end{array}$ & $\begin{array}{c}\text { Non Makanan } \\
1.966\end{array}$ \\
\hline
\end{tabular}

Catatan: SD adalah standard deviation

Sumber: Survei Industri Mikro dan Kecil Tahunan 2014, BPS (telah diolah kembali) 
Tabel 3. Hasil estimasi korelasi antara kemitraan dengan efisiensi teknis pada Industri mikro dan kecil

\begin{tabular}{|l|l|l|l|l|}
\hline \multicolumn{2}{|c|}{ Variabel } & \multicolumn{1}{c|}{ Industri Mikro } & \multicolumn{2}{c|}{ Industri Kecil } \\
\hline & \multicolumn{1}{|c|}{ Koef. } & \multicolumn{1}{c|}{-stat. } & \multicolumn{1}{c|}{ Koef. } & \\
\hline Efisiensi teknis (TE) & & & & \\
\hline Konstanta & $6.511^{\star \star \star}$ & 0.000 & $5.387^{\star \star}$ & 0.002 \\
\hline Kemitraan & $0.047^{\star \star}$ & 0.042 & 0.127 & 0.241 \\
\hline Usia usaha (laki-laki=1, & $-2.230^{\star \star}$ & 0.024 & $1.118^{\star \star \star}$ & 0.684 \\
\hline $\begin{array}{l}\text { Jenis kelamin pemilik usaha } \\
\text { perempuan=0) }\end{array}$ & & & & 0.135 \\
\hline Edukasi pemilik usaha & $0.045^{\star \star \star}$ & 0.000 & $0.116^{\star \star \star}$ & 0.000 \\
\hline Proporsi jumlah tenaga kerja perempuan & $-0.850^{\star \star \star}$ & 0.000 & $-2.935^{\star \star \star}$ & 0.000 \\
\hline Proporsi jumlah tenaga kerja produksi & $1.127^{\star \star \star}$ & 0.000 & -0.346 & 0.661 \\
\hline Proporsi jumlah tenaga kerja tidak dibayar & $-5.668^{\star \star \star}$ & 0.000 & $-3.982^{\star \star \star}$ & 0.000 \\
\hline Modalluar (>50\%=1,<50\%=0) & $0.247^{\star \star}$ & 0.027 & 0.105 & 0.698 \\
\hline Wilayah usaha (kota=1, desa=0) & $0.403^{\star \star \star}$ & 0.000 & 0.078 & 0.755 \\
\hline Sektor (non makanan=1, makanan=0) & $1.046^{\star \star \star}$ & 0.000 & -0.316 & 0.274 \\
\hline Observasi & 22.971 & & 2.525 & \\
\hline
\end{tabular}

Catatan: * $p<0.1, * \star p<0.05, * \star * p<0.01$

Sumber: Survei Industri Mikro dan Kecil Tahunan 2014, BPS (telah diolah kembali)

Penelitian ini memiliki kelemahan, terutama karena terbatasnya data survei dan sifatnya yang cross-sectional. Diantaranya adalah penelitian ini hanya dapat melihat korelasi atau hubungan kemitraan dengan efisensi teknis perusahaan, tetapi belum mampu menjelaskan hubungan kausalitas antara keduanya. Maka, sekalipun ada korelasi antara kemitraan dengan efisiensi teknis perusahaan pada industri mikro, belum dapat diartikan secara mutlak bahwa peningkatan efisiensi teknis ini disebabkan oleh kemitraan usaha. Dari sisi data kemitraan, informasi terbatas pada sumberdaya yang dikerjasamakan, sementara informasi lain seperti aktivitas kemitraan (waralaba, sub-kontrak, joint venture, dll), serta skala usaha mitra (usaha mikro, usaha kecil, usha menengah, usaha besar) yang menjadi proksi kemampuan sumber daya perusahaan tidak tersedia. Sesungguhnya informasi ini penting untuk membangun variabel kemitraan yang lebih komprehensif untuk menghasilkan estimasi yang lebih baik. Namun demikian, penelitian ini sudah mengupayakan secara maksimal informasi data tersedia dengan mengedepankan metode yang dipakai. Dari sisi pengukuran variabel kemitraan misalnya, penelitian sudah mencoba menangkap informasi kemitraan menurut sumberdaya yang tersebar melalui indeks sehingga diharapkan informasi yang luas dan beragam dapat terwakili tanpa meninggalkan esensi atau informasi penting didalamnya.

\section{Kesimpulan dan Rekomendasi}

Hubungan kemitraan usaha dengan efisiensi teknis menunjukkan kecenderungan yang berbeda pada dua kelompok industri. Kemitraan usaha terbukti memberikan efek positif yang kuat pada efisiensi teknis di industri mikro. Sebaliknya, korelasi antara kemitraan usaha dan efisiensi teknis tidak ditemukan pada industri kecil. Perbedaan ini menunjukkan bahwa kemitraan usaha di Indonesia hanya bekerja pada unit usaha dengan skala terkecil, yang memiliki kendala sumberdaya relatif lebih besar dibandingkan dengan usaha yang lebih besar. Temuan ini sesuai dengan hipotesis awal penelitian, yaitu kemitraan usaha dilakukan sebagai strategi memperoleh sumberdaya untuk meningkatkan efisiensi teknis.

Perbedaan hasil estimasi pada kedua kelompok industri menunjukkan bahwa kemitraan tidak serta merta menjadi penawar atas seluruh permasalahan sumberdaya dan memperbaiki masalah efisiensi teknis, tetapi relevansinya sangat tergantung pada skala usaha perusahaan. Berdasarkan hasil ini, kemitraan disarankan dan perlu dilakukan untuk industri mikro, tetapi 
tidak industri kecil. Dari sudut pandang perusahaan, penelitian ini memberikan petunjuk awal sebagai pengetahuan perusahaan dalam kemitraan. Dengan memahami kondisi dan skala usaha industri, kuasa perusahaan dapat memutuskan untuk bermitra atau tidak dengan pihak lain. Dari sisi pemerintah atau pembuat kebijakan, temuan ini menunjukkan bahwa kebijakan yang mendorong kemitraan tidak dapat digeneralisasi pada IMK di Indonesia.

Beberapa rekomendasi yang dapat disampaikan adalah pemerintah perlu mengkaji dengan lebih spesifik target dan bentuk-bentuk kemitraan usaha yang perlu didorong dan yang dapat diusahakan secara mandiri oleh industri. Berdasarkan hasil penelitian, pemerintah perlu fokus pada instrumen kemitraan usaha bagi industri mikro melalui kebijakan afirmatif karena terbukti memberikan manfaat yang signifikan. Sedangkan, kemitraan usaha pada industri kecil misalnya, seluruh proses dapat diserahkan pada mekanisme pasar. Selain itu, untuk dapat memperoleh informasi yang lebih dalam mengenai hal ini, penting disediakan basis data bersifat time-series yang lengkap dan dapat diperbandingkan di dunia internasional. Data Survei Industri Mikro dan Kecil, yang merupakan satu-satunya data resmi nasional, hanya melihat kemitraan dari sisi individu/ perusahaan sebagai subyek yang pasif atau penerima manfaat. Interaksi perusahaan, misalnya kontribusi pada mitra dan informasi hubungan kemitraan usaha (joint-venture, produsen-pembeli, waralab, dII) tidak tersedia. 


\section{Daftar Pustaka}

Admassie, A., \& Matambalya, F. S. (2002). Technical Efficiency of Small Medium Scale Enterprises: Evidence from Survey of Enterprises in Tanzania. Eastern Africa Social Science Research Review 18(2), 1-29.

Alvarez, R. \&. Crespi, G. (2003). Determinants of Technical Efficiency in Small Firms. Small Business Economics, 20: 233.

Bardasi, E., \& Sabarwal, S. (2011). How do female entrepreneur perform? Evidence from three developing regions. Small Business Economic, Vol 37:417-441.

Batra, G., \& Tan, H. (2003). SME Technical Efficiency and Its Correlates: Cross-national Evidence and Policy Implication. Washington, DC: World Bank Institute.

Berry, A., \& Mazumdar, D. (1991). Small-scale Industry in The Asian-Pasific Region. Asian Pacific Economic Literature.

Berry, A., \& Rodrigues, E. S. (2001). Firm and Group Dynamics in the Small and Medium Enterprises Sector in Indonesia. Washington, D.C.: World Bank Institute.

Burki, A., \& Terrell, D. (1998). Measuring Production Efficiency of Small Firms in Pakistan. World Development.

Charoenrat, T., Harvie, C., \& Amornkitvikai, Y. (2013). Thai Manufacturing Small and Medium Sized Enterprise Technical Efficiency: Evidence from Firm-Level Industrial Cencus Data. Journal of Asian Economics 27, 42-56.

Coelli, T. J., Rao, D. P., O’Donnell, C. J., \& Battesse, G. E. (2005). An Introduction to Efficiency and Productivity Analysis. New York : Springer.

Essien, A. E. (2007). Technical Efficiency of Small and Medium Scale Industries in Nigeria: Evidence From Nation-Wide Sample Survey. Studia Universitatis babes-Boyal.

Filmer, D., \& Pritchett, L. (2001). Estimating Wealth Effect without Expenditure Data-or tears: an Application to Education Enrollment in States of India. Demography.

Fischer, E. M., \& Dyke, L. S. (2011). A theoretical overview and extensions of research on sex, gender, and entrepreneurship. Journal of Business Venturing, Vol 8: Issue 2.

Franco, M., \& Heiko, H. (2015). Interfirm Alliances: A Taxonomy of SMEs 48. Long Range Planning, 168-181.

Genc, N., \& İyigün, N. Ö. (2011). The Role of Organizational Learning and Knowledge Transfer in Building Strategic Alliances: A Case Study. Procedia - Social and Behavioral Sciences.

Hanna, V., \& Kathryn, W. (2008). Interfirm Cooperation among Small Manufacturing Firm. International Small Business Journal, 299.

Hayashi, M. (2001). The Role of Subcontracting in SME Development in Indonesia: Micro-level Evidence from The Metalworking and Machinery Industry. Journal of Asian Economics, 13(1): 1- 26.

Hill, H., \& Kalijaran, P. (1993). Small Enterprise and Firm-level Technical Efficiency in The Indonesian Garment Industry. Applied Economics, 25: 9.

Jovanovic, B. (1982). Selection and the Evaluation of Industry. Econometrica, 50, No.3, 649 670.

Liedholm, C. (2002). Small Firm Dyamics: Evidence from Africa and Latin America. Small Business Economics, 18:227-242.

Loveman, G., \& Sengenberger, W. (1991). The re-emergence of small-scale production: An international comparison. Small Business Economics.

Malecki, E., \& Tootle, D. (1996). The Role of Networks in Small Firm Competitivenes. International Journal of Technology Management 11(1-2), 43-57.

Margono, H., \& C., S. S. (2006). Efficiency and Productivity Analyses of indonesian Manufacturing Industries. Journal of Asian Economics, 17: 979-995.

Marino, L. D., \& al, e. (2008). Environmental Shocks. Baylor University.

Nadvi, K. (2007). The cutting Edge: Collective efficiency and international competitiveness in Pakistan. Oxford Development Studies, 87-107.

Nichter, S., \& Goldmark, L. (2009). Small Firm Growth in Developing Countries. World Development.

Phan, H., Dao, T., \& Reilly, B. (2009). Efficiency in Vietnamese Manufacturing Sector. Journal of International Development. 
Pitt, M. M., \& Lee, L.-F. (1981). The Measurement and Sources of Technical Inefficienccy in The Indonesian Weaving Industry. Journal of Development Economics, 9: 43-46.

Pyke, F., \& Sengenberger, W. (1992). Industrial Districts and Local Economic Regeneration. International Labour Organisation.

Samad, Q., \& Patwary, F. (2002). Technical Efficiency and Technical Change in The Major Manufacturing Industries of Bangladesh. The Bangladesh Development Studies, 28: 113-135.

Schmitz, H. (1982). Growth Contraint on Small-scale Manufacturing in Developing Countries: A Critical Review. World Development, 429-450.

Schmitz, H. (1999). Collective Efficiency and Increasing Returns. Cambridge Journal of Economics.

Schmitz, H. (2007). Collective Efficiency: Growth Path for Small-scale Industry. The Journal of Development Studies.

Badan Pusat Statistik. (2014). Survei Industri Mikro dan Kecil Tahunan.

Tambunan, T. (2007). Transfer of Technology to and Technology Diffusion among Non-farm Small and Medium Enterprises in Indonesia. Knowledge, Technology and Policy, 20:243-258.

Tambunan, T. (2008). Development of SME in ASEAN. New Delhi: Redwhorty.

Taymaz, E. (2005). Are Small Firms Really Less Productive? Small Business Economic, 5:429 445.

Tran, K., \& Tsionas, E. G. (2015). Endogeneity in stochastic frontier models: Copula approach without any external instruments. Economic Letters, 133: 85-88.

Tran, T., Grafton, R., \& Kompas, T. (2008). Firm Efficiency in a Transitional Economy: Evidence from Vietnam. Asian Economic Journal 22(1), 47-66.

Urata, S. (2000). Policy Recommendation for SME Promotion in The Republic of Indonesia. Japan International Cooperation Agency. 